\title{
The Punishment of the Hellespont by Xerxes: Perception of Religious Behaviour of the Enemy in Conflict Situations
}

Dominique Briquel

(Sorbonne University, École Pratique des Hautes Études, Paris)

\begin{abstract}
The Persian king Xerxes, when he attacked Greece in 480 B.C., built a bridge over the Hellespont which was destroyed by a storm. His behaviour was interpreted by Greek observers as an act of hybris, the intolerable pride of a human who could not accept his limits. But the true meaning was quite different: according to ideas which go back to Indo-European prehistory, a hero had to prove his value by overcoming the opposition of water. This was a consequence of the concept of "fire in water", which can be reconstructed from many parallels outside Iran - e.g. Rome, Ireland and even Greece.
\end{abstract}

\section{Keywords}

comparatism; Dumézil; Herodotus; Indo-European ideology; Persian king

Indo-European comparatism can sometimes shed new light on examples of behaviour which, even in antiquity were not understood in their real meaning, especially when they were observed from outside. So Greeks were not always able to interpret in their true sense facts performed by Barbarians, which seemed strange or even scandalous, but can be explained by religious beliefs or ideas that in some cases were a legacy of IndoEuropean ideology, as studied by Georges Dumézil. Xerxes' scourging of the Hellespont, known by Greek sources, seems to provide a good example of such misunderstanding.

The Greek historian Herodotus, who lived in the 5th century B.C., was already held by the Roman Cicero as "the father of history": his work is the first historical inquiry in classical literature. Indeed, the scope of his enterprise was a true historical one, far away from the mere registration of facts that could exist in local chronicles, which probably existed before him. He lived in the period of the so called Medic wars, during which, twice in the early 5th century, the Persian Empire, which was surely the most important power in that time, tried to subdue Greece, the first time in 490 under Persian king Darius, the second time, ten years later, under his son Xerxes. Both times, the attempt failed: in 490 in Marathon and in 480 in Salamis, and Athens, which was the Greek city 
which alone defeated Persian troops in the first war and had the main part, during the second one, in the common naval victory was so proud of having so preserved the liberty of the whole Greece that, when Herodotus began his work, he could scarcely avoid to treat what was the great historical problem of his time, that is to explain how tiny Greece could have defeated such a great empire as Persia, whose king dominated nearly all known countries in Asia, Egypt and also some parts of Europe.

In a rather understandable way, Herodotus saw the victory of the Greeks as the victory of Hellenic city-state, the polis, and its conception of civilization against the Barbarian idea of political organization, which let no place to individual freedom and gave all power to a sole all-mighty despot. We are precisely in the period in which, to a great extent as a consequence of Medic wars, the dichotomy between Barbarians and Greeks becomes a central concept in Greek thought and therefore Hellenes were perhaps still less able to understand Barbarian customs when they differed from their own than they had been before. Sure Herodotus, with his inquisitiveness of mind, his interest in foreign customs, was better prepared to accept ways of life which could seem scandalous to his fellow-citizens. He recalled that some Indians ate the corpses of their deceased fathers as a mere sign of the relativity of ethical ideas, without being indignant of it (3. 38). Nor he criticized Lydian women for practicing ritual prostitution (1. 93-94). Therefore he gained the reputation of being philobarbaros, and it was one of the grievances that Plutarch made against him in his little treatise On Herodotus' malignity.

But this does not mean that even Herodotus was free from prejudice about Barbarians, and here we shall examine a case in which, narrating an episode of the second Medic war, he did not realize the Persian way of making war and misunderstood what was, among them, a religious attitude, reducing it to the impious arrogance of an oriental despot. The event we will take into consideration happened at the beginning of the campaign, as the huge Persian army - according to Herodotus, it counted over one million and half men - crossed the Hellespont, the strait between Asia and Europe. The Persian engineers built a bridge, on which the troops could march, but the first one they set up was destroyed by a storm. The king's reaction was so described by Herodotus:

"But no sooner had the strait been bridged than a great storm swept down and brake and scattered all that work. When Xerxes heard of that, he was very angry and gave command that the Hellespont be scourged with three hundred lashes and a pair of fetters to be thrown into the sea; nay, I have heard now that he sent branders with the rest to brand the Hellespont. This is certain, that he charged them while they scourged to utter words outlandish and presumptuous: 'Thou bitter water, they should say, our master thus punishes thee, because you didst him wrong albeit he had done thee none. Yea, Xerxes will pass over thee, whether thou wilt or no; it is but just that no man offers thee sacrifice, for thou art a turbid and a briny river.' Thus he commanded that the sea be punished and that they who had been overseers of the bridging of the Hellespont should be beheaded."

1 Herodotus 7.35-36 (transl. A. D. Godley, The Loeb Classical Library). On this text, see Briquel \& Desnier (1983) and now Dan (2015); also Herrenschmidt \& Lincoln (2004) and Lincoln (2007: p. 128) for the contrast between sweet and salt water. 
In this text, king Xerxes appears like a perfect model of what the Greeks called hybris, unbounded ambition and lack of sense of human limits. His pride as a king let him refuse to admit that man is powerless against the natural forces, and the gods who are beyond them. Being master of his subjects, he claimed to be master of the universe and to submit it to his own will. From a Greek point of view, he completely lacked common sense and behaved as a mere despot: thus it could be expected that, later, the gods punished him and inflicted him defeat in front of the Hellenes, who had righter conception of human condition and its limits.

But, if Greeks, like Herodotus and his readers, would have immediately interpreted as a manifestation of reprehensible pride the king's behaviour, it is not certain that it was the way in which their Persian enemies perceived it. Xerxes' punishment of the Hellespont seemed to be an extravagant gesture of a tyrant, unable to admit that he was not all-mighty as he pretended to be and he appears, even to our modern eyes, as a negative figure, justly defeated by his Greek adversaries, champions of freedom and humanism. But it chances to be a misinterpretation of a behaviour, which should not be taken as a negative one. Xerxes trying to force waters to obey him is not an isolated figure in Persian history and, as we will see, sometimes such a behaviour can be encountered for persons who may be regarded as rather positive: indeed, unlike Xerxes, they suffered no defeat after treating in that manner the forces of nature, but their gesture was followed by a clear victory.

In another book, Herodotus recalls how a predecessor of Xerxes, king Cyrus, met the opposition of water - that of the river Gyndes, in which his sacred horse drowned while he was marching against Babylon. He too decided to punish the water, and stopped his army to let her dig canals in order to exhaust the river. He set his troops again in motion only after achieving this work, and then took Babylon. Here is Herodotus' text:

"When Cyrus on his way to Babylon came to the river Gyndes, which rises in the mountains of the Matieni and flows through the Dardanean country into another river, the Tigris, which again passes the city of Opis and issues into the Red Sea - when Cyrus, I say, essayed to cross the Gyndes, it being there navigable, one of his sacred white horses dashed recklessly into the river that he might win through it, but the stream whelmed him and swept him under and away. At this violent deed of the river Cyrus was very wroth and he threatened it that he would make it so weak that women should ever after cross it without wetting her knees. Having so threatened he ceased from his march against Babylon and, dividing his army into two parts, he drew lines planning out a hundred and eighty canals running every way from either bank of the Gyndes; then he arrayed his army along the lines and bade them dig. Since a great multitude was at the work it went with all speed; yet they spent the whole summer there before it was finished. Then, at the opening of the second spring, when Cyrus had punished the Gyndes by parting it among the three hundred and sixty canals, he marched at last against Babylon." ${ }^{2}$

2 Herodotus 1.189-190. See our study in Briquel (1981). 
In this story, Cyrus succeeded in his military enterprise: he conquered Babylon and therefore his behaviour while attempting to impose his will upon the river Gyndes cannot be considered as a sin against supernatural powers, a sign of hybris. On the contrary, he so proved that he was able to beat the resistance of his opponents and his success against the Gyndes was not indifferent to his later victory over Babylon. It is not a mere chance if the way he used to take Babylon remembers that in which he subdued the river Gyndes his troops entered the city approfitting the fact that the king had previously drawed off the river Tigris, permitting his soldiers passing through its flow, which Babylonians had left unguarded. In the capture of the city too, Cyrus was victorious thanks to the right use of hydraulical technics.

So, for a Persian king, proving himself to be able to surpass the opposition of waters, or gettting help of them in his military achievements, or benefitting from a prodigy that showed his mastery of waters was held as a most favourable sign. We have many examples of this idea, all along the history of ancient Iran. For instance, when he conquered Ninivy and defeated its king Sardanapalos, Arbakes, king of Media, gained the aid of the river Tigris, which destroyed the wall of the city of his enemies. Much later, a short time before the collapse of Persian monarchy before Alexander the Great, the pretender to the throne, Cyrus the Younger, marching with his troops against Babylon, was stopped by a sudden flood of the river Euphrates. But, during the night, the rising of the river disappeared: this was held by the neighbouring people as a sign of his divine election and capacity for becoming king. The same can be related about foreign invaders entering the country: such signs foretold their future victory and conquest. We find this kind of narrative in Alexander's story. Plutarch says, in his Life of Alexander (17. 4-6), that the Macedonian, when he pushed forward his army along the Pamphylian coast, saw the sea withdrawing before him, so that he could pass at the foot of sheer cliffs, which usually were beaten by the waves. So the Greek conqueror also profited the same kind of prodigies Persian kings were used to encounter. Still later, according to the same Plutarch, in his Life of Lucullus (24), as the Roman general Lucullus arrived to the river Euphrates, its waters lowered, in the same manner as it had happened in the time of Cyrus the Younger three centuries earlier: stroken by this prodigy, the inhabitants prostrated themselves before him. ${ }^{3}$

As these examples show, we find here a recurrent motive, occurring in Persian areas, or areas submitted to Persian influence. Its sense is to prove the capacity of a commander to gain victory over his enemies, and to obtain therefore favour of the gods. Sometimes the gods seemed to give willingly their agreement: in the cases of Arbakes, Cyrus the Younger, Alexander, Lucullus there was no opposition from the liquid element that the commander had to surpass to prove his ability to be victorious. But it was not always so. When attacking Babylon and encountering the opposition of the river Gyndes, Cyrus the Elder had to force waters to admit his superiority: but, as we have seen, this mastery of the reluctant waters - done by an appropriate use of technical means - was linked to the king's later victory over Babylon, appeared therefore to be a condition of its possibil-

3 All these examples have been studied by J.-L. Desnier, in Desnier (1995: pp. 23-25, Sardanapalos; pp. 21-22, Cyrus the Younger; pp. 27-30, Alexander; pp. 51-54, Lucullus). 
ity. Thus, acting so against the opposition of waters, the Persian king should not be taxed with impiety. Even if he used violent coercion, his later success showed he obtained the help of gods in the war in which he was involved.

All these figures are positive ones, even when they behaved in the same violent way against the forces of waters as Xerxes as he ordered the Hellespont to be scourged. So we see how insufficient the Greek vision of this event was, as reported in Herodotus' work. We find in that story an old Persian scheme, in which a positive hero had to prove his capacity by his ability to get, even by force, the submission of waters and the help of the gods who presided over them. His behaviour has to be considered as a kind of ordeal, in which he proved his quality as a hero.

Behind this recurrent story, we can recognize a pure Iranian concept, deeply rooted in the idea of power and of sovereignty among Old Persian peoples: that of xvaranah, i.e. this kind of luminous halo which surrounded the head of the legitimate king and was considered as the perceptible sign of the divine protection he enjoyed. ${ }^{4}$ In practice, the xvaranah was a privilege of the Persian king, but it was not conceived as belonging automatically to him. He could loose it, if he committed sins against the gods: in the story of the first king figure of ancient Iran, Yima, we are told how the sovereign was deprived of his halo of glory, which went to other heroes. ${ }^{5}$ He had too to get possession of it: and here we shall find the exact meaning of the stories we are examining.

The story of the xvaranah is related in the Avesta, in the 19th Yast, called "Yast of the earth". ${ }^{6}$ As it can be expected in the dualistic view of Iranian religion, this "glory of the Kavi" (kavaem xvaranah) was contested between forces of good and forces of evil, and we are told that Good Spirit and Evil Spirit (Spanta Mainyu and Anra Mainyu) disputed its possession. But none of them could succeed in gaining it. Then the god of water, Apam Napat (whose name means properly "descendant of waters") seized it and brought it into the mythical lake Vourukasa, where it now lies under his guard.

But the xvaranah is not fated to remain there indefinitely. The supreme god Ahura Mazda, the head of the good deities, offers it as a scope to the ambitions of men, so that they try to get it. And the following part of the Yast recounts the unsuccessful attempt of the Turanian Franrasyan to appropriate it. But, as a stranger and enemy of Iranian people, the Turanian was not qualified to get the possession of the luminous glory, which belongs only to "Aryan nations, born and not born, and to the just Zarathustra". Therefore his attempts failed and the xvaranah remained in the sacred lake.

This story - and the parallel stories among other Indo-European peoples studied by G. Dumézil - tells us of the failure of a negative figure to get control of the xvaranah. But the positive counterpart existed, i.e. a kind of story in which a positive hero, attempting to seize this "glory of the Kavi", succeeded in his enterprise and so appeared as legitimate possessor of it. This positive version of the tale, not taken into account by G. Dumézil, is that reflected in the texts we have examined. But the xvaranah does not

4 On that concept, see ultimately Haudry (1994: in part. pp. 263-264), Lubotsky (1998), Kellens (19971998: in part. p. 742). Also Dumézil (1973: pp. 24-34).

5 See Dumézil (1971: pp. 282-286).

6 See the analysis in Dumézil (1973: pp. 24-27). 
accept to be conquered without resistance: even qualified persons have to surpass the opposition of its divine guardian, the god of waters Apam Napat. The hero is involved in a struggle with him, has to prove that he may become the right owner of that imperishable glory. His behaviour in those circumstances, where he has to beat the resistance of the liquid element, should therefore not be considered as a sign of impiety: the hero is submitted to an ordeal by Apam Napat and has to become victorious against waters.

So, from an Iranian point of view, Cyrus was perfectly right in spending time to "punish" the river Gyndes and even did so Xerxes, this enemy of the Greeks, as he let his men overcome the resistance of the Hellespont. They could in that way prove they were agreed by the gods and, normally, such a behaviour should have let them to victory in the war in which they were involved: sure, Cyrus was victorious, but not Xerxes. But it does not hinder that, according to Persian concepts, he was right in doing what he did as he crossed the Hellespont.

But Greeks, and even a so acute Hellenic observer as Herodotus, were unable to seize the religious meaning of such a behaviour and considered it according to their own concepts: for them, it was nothing else as a sign of contempt of gods, of hybris. However, it may seem to be a lack of perception of a religious reality which was not so alien to Greek thought as they perceived it. Indeed, as G. Dumézil showed, the Iranian xvaranah is related to an old concept, which was wide-spread among Indo-European peoples: that of "fire in water". For Indo-European thought, the apparently contrary elements of fire and water were closely related together and fire might be considered as born from water - as shown by lightning falling from clouds which bring rain, or by burning wood, where fire appears in a material nourished by water. Thus was developed the concept of "descendant of waters" god - who is a deity of waters, but controlling fire that is hidden in it. The Indo-Iranian god Apam Napat is the clearest expression of this divine figure, but G. Dumézil proposed to interpret in the same way the Roman god Neptunus - who would have been the grandson, nepos, of water - and the Irish tale-figure Nechtan, who owns an explosive well (in which the nature of "fire in water" is conspicuous), who both bear names based on the same origin as Indo-Iranian Napat. ${ }^{7}$

This concept of "fire in water" and its divine possessor, the "descendant of waters" god had not only naturalistic aspects, as an expression of the links existing between physical elements of fire and water in the universe. As shown by the Iranian xvaranah, the power of this correlation of both elements was conceived in relation to sovereignty and the power of the king was perceived as related to it. Who possessed the "fire in water" was able to rule the country. This idea can be found not only in Iranian area, but also elsewhere. G. Dumézil emphasized the analogies between the story of the xvaranah, as related in Yast 19, that of the explosive well of Nechtan in Ireland and, in Italy, the tradition about the fall of the great Etruscan rival of Rome, the neighbour city of Veii. ${ }^{8}$

7 See Dumézil (1973: pp. 21-24, Apam Napat; pp. 27-34, Nechtan; pp. 34-38, Neptunus).

8 See Dumézil (1973: pp. 39-85). 
This last example is especially relevant for our Persian stories. During the war which ended with the taking of the Etruscan town, which, during centuries, had been a constant enemy of Rome, ${ }^{9}$ occurred a prodigy: as the Roman army besieged Veii, the water of the Alban Lake suddenly grew higher and threatened to pass over the ridge of the mountains surrounding it. This was obviously a manifestation of the wrath of the gods, what Romans called ira deorum, and especially of the deity presiding over waters, Neptune. But we may recognize in such an eruption a Roman occurrence of the IndoEuropean "fire in water" theme: Alban lake blows up like, in the Irish tale, the well of Nechtan. As usual in such circumstances, this phenomenon was held as a prodigy, i.e. a sign sent by the gods to the mortals, whose sense had to be deciphered. Normally, these prodigies, at Rome, were interpreted by Etruscan specialists, the haruspices, but the state of war between Rome and Veii did not allow to have recourse to Tyrrhenian soothsayers. But, fortunately, an Etruscan haruspex from Veii was captured by a Roman soldier, acting as sentinel in front of the enemy city, and he gave the explanation of the prodigy: Rome would gain victory over Veii if they could master the waters of Alban lake, preventing them to flow into the sea. The Romans made the necessary hydraulic works and so contained the water of the lake. In that way, they proved to be masters of the liquid element and, consequently, their army, commanded by Camillus, took the Etruscan city, after a siege which, the tradition asserts, lasted as long as the siege of Troy by the Acheans. ${ }^{10}$ Like in the case of Cyrus' campaign against Babylon, the way in which the Romans proceeded to enter the city of their enemies recalls the way in which they mastered the water of the Alban lake. Camillus' soldiers penetrated the citadel of the Etruscan city passing through a tunnel, which remembers those dug on the slopes of the Alban hills to pump the water. Here we find another story quite comparable with that of Cyrus and the river Gyndes. Rome, like the Persian king, can be held as a positive figure and the fact that it overcame the manifestation of "fire in water" was a proof of her positive character and a promise of rapid victory over Veii. ${ }^{11}$

But Romans and Iranians were not the only peoples among Indo-Europeans to have traces in their national traditions of this kind of story. After G. Dumézil's recognition

9 As shown by J. Hubaux (1958: pp. 60-107), Veii was taken by the Romans in the 365th year of its existence, thus at the end of a "great year". In a cyclical conception of time and history, the rivalry between both towns occupied a whole cycle of Rome's story, until she defeated her Etruscan enemy.

10 This detail shows that, for the Romans, the siege of Veii had the same value as the Trojan war for the Greek tradition. This analogy has already been noticed by B. G. Niebuhr (1812: p. 237): "Veji ist das von alter römischen Dichtkunst nachgebildete Ilion: daher die zehnjährige Belagerung, gegen Annalen und Möglichkeit”.

11 Thus the story has to be considered as putting Rome in a positive light: it belongs to the category of narratives in which a positive hero is confronted with the power of the "fire in water". Therefore, the episode has a favourable end. G. Dumézil, who did not take into account the existence of a positive version of this mythical scheme, wanted the story of the eruption of the Alban lake to be identical to those of Franrasyan and Boand, the unfaithful wife of Nechtan: he considered that the sense of the whole story was to emphasize the fault of Roman magistrates, who had made a ritual error while celebrating the festival on the Alban hill. But he was thus constrained to hold as a secondary development the connection of the story with the siege of Veii, and as a reflection owed to Roman pride the positive issue for Rome. But the analogy with Cyrus' story, as told by Herodotus 1.189-190, argues against G. Dumézil's view: here we have to deal with the positive version of this old Indo-European scheme. See Briquel (1981). 
of the importance of the "fire in water" theme among Indo-Europeans, several scholars enlarged his analysis, taking into consideration other sectors, and so demonstrated the importance and fecundity of the scheme through a huge quantity of parallels. ${ }^{12}$ It is especially worth quoting the work of a French scholar, Jean-Luc Desnier, who, in two successive books, discovered many parallel stories not only in Iran and in Rome, but also in Celtic and Germanic contexts. ${ }^{13}$ Even Greece knew that kind of tradition. Several Greek myths or legends can be connected to this old Indo-European model. But it could not help Herodotus or his fellow citizens to understand the real sense of Xerxes' behaviour as he scourged the Hellespont. We may indeed find some traces of the old ordeal character of the opposition of the liquid element to a pretender to sovereignty - according to the legendary scheme we met in Iran, or in Italy with the story about the eruption of the Alban lake. But the motive survived in Greece in myths like those of the contest between Poseidon and other deities for the sovereignty over several countries or cities: he lost not only in his famous contest with Athena for Attica, but also with Helios for Corinth, Hera for Argolis, Apollo for Delphi, Zeus for Egina, Dionysos for Naxos. ${ }^{14}$ These stories can always be analyzed as based on the old theme of the contest between a positive hero and the divine master of the waters and the fire which was hidden in them. But Poseidon was a pure anthropomorphic figure and such narratives retain nothing of the naturalistic aspects of the contest, so perceptible in the Iranian or Roman parallel stories. Besides, these Greek legends regarded the primitive history of those countries, were also relegated in a remote past. They have nothing to do with the behaviour of the Greeks in the present and, especially, are never encountered in the narration of their present conflicts. That the Hellens still preserved some traces of the old Indo-European "fire in water" theme could not help them to get a better understanding of the true meaning of the behaviour of the Persian king as he let his soldiers scourge the Hellespont.

\section{Bibliography}

Allard, J.-P. (1999). De l'or des Scythes à l'or du Rhin. Études indo-européennes, 16, 67-118.

Briquel, D. (1981). Sur un passage d'Hérodote: prise de Babylone et prise de Véies. Bulletin de l'Association Guillaume Budé, 1(3), 293-306.

Briquel, D. (1985). Vieux de la Mer grec et Descendant des Eaux indo-européen. In R. Bloch (Ed.), Recherches sur les religions de l'Antiquité classique, 2, D'Héraklès à Poséidon, mythologie et proto-histoire (Hautes Études du Monde Gréco-Romain, 14; pp. 141-185). Genève-Paris: Droz-Champion.

12 After two articles by J. Puhvel (1973) and C. Scott Littleton (1973), we may quote, among other works, a book of C. Sterckx (1994) on Greek and Celtic data, a study of Greek data made by B. Sergent (2004: pp. 476-477), two contributions about Germanic legends (Haudry 1994; Allard 1999), an article of M. Meulder (2000) dealing with Roman tradition. We have personally studied Iranian traditions (Briquel 1981; Briquel \& Desnier 1983), Greek data (Briquel 1985; 1988), a story regarding ancient Dacia (Briquel 2006-2007) and Roman parallels (Briquel 1998; 2007: pp. 310-319 ). For a list of occurrences, Briquel (2007: p. 312, n. 49).

13 J.-L. Desnier, in Desnier (1995; 1997; also 1998).

14 See for the data Briquel (1988: in part. pp. 58 and 63, with notes 28-30). 
Briquel, D. (1988). La comparaison indo-européenne dans le domaine grec: l'exemple de Poséidon. In Ch. M. Ternes (Ed.), Actes du colloque international "Éliade - Dumézil", Luxembourg, avril 1988 (pp. 51-64). Luxembourg: Courrier de l'Éducation Nationale.

Briquel, D. (1998). Les Tarquins de Rome et les trois fonctions de l'idéologie indo-européenne: 1) Tarquin l'Ancien et le dieu Vulcain. Revue de l'Histoire des Religions, 215, 369-395.

Briquel, D. (2006-2007). Le trésor du roi Décébale: à la recherche de représentations religieuses des anciens Daces (à propos de Dion Cassius, 68, 14, 3). In P. Bonnechère, \& G. Cursaru (Eds.), Actes de la VIe conférence annuelle de l'European Association of Sciences of Religion, Religious History of Europe and Asia, Bucarest, 20-23 septembre 2006 (Les Études Classiques, 75, 2007; pp. 5-22). Namur: Soc. des Études Classiques.

Briquel, D. (2007). Mythe et révolution. La fabrication d'un récit: la naissance de la république à Rome (Collection Latomus, 308). Bruxelles: Latomus.

Briquel, D., \& Desnier, J.-L. (1983). Le passage de l'Hellespont par Xerxès. Bulletin de l'Association Guillaume Budé, 1(1), 22-30.

Dan, A. (2015). Grecs et Perses sur les Détroits: le démon enchaîné et la démesure du Grand Roi. Ancient West and East, 14, 191-235.

Desnier, J.-L. (1995). Le passage du fleuve, essai sur la légitimité du souverain (Annales Littéraires de l'Université de Besançon, 560; Centre de Recherches d'Histoire Ancienne, 143). Besançon-Paris: L'Harmattan.

Desnier, J.-L. (1997). La légitimité du prince, la justice du fleuve: IIIe-XIIe siècles (Collection Histoire Ancienne et Anthropologie, 2). Paris: L'Harmattan.

Desnier, J.-L. (1998). Les débordements du fleuve. Latomus, 57, 513-522.

Dumézil, G. (1971). Mythe et épopée (Vol. II; Bibliothèque des Sciences Humaines). Paris: NRF-Gallimard.

Dumézil, G. (1973). Mythe et épopée (Vol. III; Bibliothèque des Sciences Humaines). Paris: NRF-Gallimard.

Haudry, J. (1994). Le feu des eaux. In Ch. Kircher-Durand (Ed.), Nomina rerum, hommage à Jacqueline Manessy-Guitton (Centre de Recherches Comparatives sur les Langues de la Méditerranée Ancienne, 13; pp. 259-272). Nice: Université de Nice-Sophia-Antipolis.

Herrenschmidt, C., \& Lincoln, B. (2004). Healing and Salt Waters: The Bifurcated Cosmos of Mazdean Religion. History of Religions, 43, 269-283.

Hubaux, J. (1958). Rome et Véies. Recherches sur la chronologie légendaire du moyen âge romain (Bibliothèque de la Faculté de Philosophie et Lettres de l’Université de Liège, 145). Paris: Les Belles Lettres.

Kellens, J. (1997-1998). De la naissance des montagnes à la fin des temps: le Yast 19. Annuaire du Collège de France, 737-765.

Lincoln, B. (2007). Religion, Empire and Torture. The Case of Achaemenian Persia, with a Postcript on Abu Ghraib. Chicago-London: The University of Chicago Press.

Lubotsky, A. M. (1998). Avestan xvaranah: the Etymology and Concept. In W. Meid (Ed.), Sprache und Kultur der Indogermanen, Akten der X. Fachtagung der Indogermanischen Gesellschaft Innsbruck, 22. -28. September 1996 (Innsbrucker Beiträge zur Sprachwissenschaft, 93; pp. 479-488). Innsbruck: Institut für Sprachwissenschaft.

Meulder, M. (2000). Le feu et la source à Rome. Latomus, 59, 749-765. 
Niebuhr, B. G. (1811-1812). Römische Geschichte (Vol. I-II). Berlin: Realschulbuchhandlung.

Puhvel, J. (1973). Aquam exstinguere. Journal of Indo-European Studies, 1, 379-386.

Scott Littleton, C. (1973). Poseidon as a Reflex of the IE "Source of Waters" God. Journal of Indo-European Studies, 1, 423-440.

Sergent, B. (2004). Celtes et Grecs, 2: Le livre des dieux. Paris: Payot.

Sterckx, C. (1994). Les dieux protéens des Celtes et des Indo-Européens (Société Belge d'Études Celtiques, Mémoires, 4). Brussels: Société Belge d'Études Celtiques.

Dominique Briquel / dominique.briquel@paris-sorbonne.fr

Professor at Université de Paris-Sorbonne (Paris IV), Literature and civilizations

École Pratique des Hautes Études, Paris, France 